\section{Conclusion}

This pilot study has established the feasibility and acceptability of such placements. More specific educational goals for psychiatry should include understanding of the specialist/GP interface, early presentation of psychiatric disorders, interplay of physical and psychological processes in health and disease and the role of the GP in long-term disorders. Techniques for assessing achievement of these goals will require elaboration.

\section{Acknowledgement}

This study was funded by the Medical Manpower and Education Division, Department of Health. Our thanks are due to the regional postgraduate Dean, Professor P. Flute and to the trainers, Dr M. O'Neill, Dr J. Reynolds, Dr M. Fisher and Dr S. Goldenberg. Dr Burns was Clinical Tutor in Psychiatry for the St George's Training Scheme during this study. Dr Silver was Regional Adviser in General Practice, South West Thames Region.

\section{References}

Crisp, A.H., Hemsi, L.K., PAykel, E.S., Storey, P.B., et al (1984) A future pattern of psychiatric services and its educational implications: some suggestions. Medical Education, 18, 110-116.

DEPARTMENT OF HEALTH (1989) Statement of Fees and Allowances (SFA) payable to General Medical Practitioners in England and Wales. (April 1989).

GASK, L., GOLDBERG, D.P., LESSER, A.L. \& MILLAR, T. (1988) Improving the psychiatric skills of the general practice trainee: an evaluation of a group training course. Medical Education, 19, 299-304.

General Medical Council Education Committee (1987) Recommendations on the Training of Specialists, October 1987. London: GMC.

KENDRICK, T., SibBald, B., BuRNS, T. \& FReEling, P. (1991) Role of general practitioners in care of long-term mentally ill patients. British Medical Journal, 302, 508-510.

*Tom Burns, Professor of Community Psychiatry, Department of Mental Health Sciences, Jenner Wing, St George's Hospital Medical School, Cranmer Terrace, Tooting, London SW17 ORE; Trevor Silver, Regional Adviser in General Practice (retired); Paul Freeling, Professor of General Practice (retired); and Arthur Crisp, Professor of Psychiatry, St George's Hospital Medical School

*Correspondence

\title{
The British Neuropsychiatry Association Prize
}

The British Neuropsychiatry Association wishes to encourage young workers in the field of neuropsychiatry and has therefore introduced the British Neuropsychiatry Prize. This prize will be awarded for an original paper of up to 7,000 words submitted on a neuropsychiatric topic. The paper could consist of original research in which the author is the prime researcher, an original review or any other original neuropsychiatric work.

The prize is open to any member or potential member of the British Neuropsychiatry Associ- ation below the level of NHS consultant or equivalent and currently carries a value of $\$ 500.00$.

Entries should be submitted to the Secretary of the Association by 1 June 1994. A panel of examiners will make the final decision and the Prize will be presented at the UK Summer Meeting to be held from 18-20 September 1994 in Manchester.

Further information: Dr J. Bird, Secretary, British Neuropsychiatry Association, Burden Neurological Hospital, Stoke Lane, Stapleton, Bristol, BS16 1QT. 